\title{
STUDI KOMPARATIF EFEK PENGGUNAAN PAKAN MANDIRI DAN PAKAN KOMERSIAL DALAM BUDIDAYA IKAN NILA SRIKANDI (Oreochromis aureus $x$ 0. niloticus) DI KABUPATEN BREBES, JAWA TENGAH
}

\author{
Shofihar Sinansari*\#, Bambang Priono*), dan Priadi Setyawan ${ }^{* * *}$ \\ *) Balai Riset B udidaya Ikan Hias \\ Jl. Perikanan No. 13, Pancoran Mas, Depok 16364 \\ *) Pusat Riset Perikanan \\ Gedung BRSDM II, Jl. Pasir Putih II, Ancol Timur, Jakarta Utara 14430 \\ **) Balai Riset Pemuliaan Ikan \\ Jl. Raya Sukamandi No. 2, Subang 41256
}

(Naskah diterima: 2 Maret 2018; Revisi final: 24 Juni 2019; Disetujui publikasi: 24 Juni 2019)

\begin{abstract}
ABSTRAK
Penelitian ini bertujuan mengevaluasi penggunaan pakan mandiri dan pakan komersil untuk pakan ikan nila srikandi di Brebes, Jawa Tengah. Pemeliharaan ikan nila srikandi dilakukan menggunakan tambak yang berukuran $\pm 3.000 \mathrm{~m}^{2}$ sebanyak tiga unit di mana setiap petak tambak disekat menjadi dua sehingga terdapat enam unit petak percobaan. Setiap unit percobaan ditebar sebanyak 10.000 ekor benih ikan. Ikan nila srikandi dipelihara selama empat bulan dan diberi pakan harian sebanyak $1 \% 2 \%$ dari bobot tubuh pada pukul $07.00,12.00$, dan 17.00. Ikan diberi pakan uji pada bulan ke-1 dan ke-2 sebanyak 1\%dari bobot tubuh, kemudian pemberian pakan ditingkatkan menjadi $2 \%$ pada pemeliharaan bulan ke-3 dan ke-4. Performa ikan nila srikandi (pertumbuhan, laju pertumbuhan, dan kelangsungan hidup) yang diberi pakan mandiri dan pakan komersil diuji dengan menggunakan uji-T. Hasil penelitian menunjukkan bahwa pertumbuhan ikan nila srikandi tidak berbeda nyata antara yang diberi pakan pakan mandiri dengan yang diberi pakan komersil $(P>0,05)$. Kemudian, hasil produksi ikan nila srikandi yang diberi pakan mandiri mencapai $2.214 \pm 172,69 \mathrm{~kg}$ dan pakan komersil $2.248,5 \pm 234,85 \mathrm{~kg}$. Berdasarkan hasil analisis usaha penggunaan pakan mandiri pada budidaya nila srikandi lebih direkomendasikan dibandingkan dengan pakan komersil.
\end{abstract}

KATA KUNCl: evaluasi pakan; ikan nila srikandi; pakan mandiri

ABSTRACTS: A comparative study on the effect of locally-produced and commercial feeds in the culture of srikandi tilapia (Oreochromis aureus x 0. niloticus) in Brebes District, Central Java. By: Shofihar Sinansari, Bambang Priono, and Priadi Setyawan

The purpose of this study was to determine the effects of locally-produced and commercial feeds on the growth of Srikandi tilapia cultured in fish farming areas of Brebes Regency, Central Java. Tilapia Srikandi were cultured in three ponds sized approximately $\pm 3,000 \mathrm{~m} 2$. Each pond was divided into two sections divided by a net, which resulted in six experimental plots. Each experimental plot was stocked with 10,000 fish seeds. Srikandi tilapia were maintained for four months and given daily feed as much as 1\%2\% of body weight with feeding timeat $07.00,12.00$, and 17.00 . The fish were given test feeds in the 1 st and 2 nd month as much as $1 \%$ of body weight. The feeding level was increased to $2 \%$ in the 3 rd and 4 th months. The performances of Srikandi tilapia (growth, growth rate, and survival) fed with the two feed types were tested using the T-test. The results showed that there was no statistically significant difference on growth performance between fish fed with locally-produced feed and commercial feed $(P>0.05)$. The total harvest of Srikandi tilapia fed with the locally produced feed reached 2,214 $\pm 172.69 \mathrm{~kg}$ and 2,248.5 $\pm 234.85 \mathrm{~kg}$ for the commercial feed. This study suggests that in terms of economic efficiency, the use of the locally-produced feed in Srikandi tilapia farming is more profitable compared to the use of commercial feed.

KEYWORDS: growth performance; srikandi tilapia fish; locally-produced feed

* Korespondensi: Balai Riset B udidaya Ikan Hias.

Jl. Perikanan No. 13, Pancoran Mas, Depok 16364, Indonesia

Tel.: + 62217520482

E-mail: shofihar@gmail.com 


\section{PENDAHULUAN}

Ikan nila merupakan ikan yang disukai oleh berbagai kalangan masyarakat untuk dikembangkan karena mudah dibudidayakan, mudah berkembang biak, dan memiliki rasa daging yang enak. Salah satu karakteristik ikan nila adalah bersifat euryhaline (dapat hidup pada kisaran salinitas yang lebar) dibandingkan dengan ikan yang lain sehingga dapat dibudidayakan di perairan payau. Berkembangnya budidaya ikan nila mendorong Kementerian Kelautan dan Perikanan merilis ikan nila unggul toleran salinitas berdasarkan Surat Keputusan Menteri Kelautan dan Perikanan Nomor KEP.09/MEN/2012 yang disebut nila srikandi (Setyawan et al., 2013).

Sifat unggul nila srikandi yang memiliki toleransi terhadap sal initas tinggi hingga mencapai 30 ppt begitu memikat para pembudidaya tambak karena dapat dijadikan alternatif komoditas budidaya selain bandeng dan udang. Budidaya ikan nila srikandi telah banyak diterapkan di beberapa daerah seperti di Kabupaten Pekalongan (Setyawan \& Dewi, 2013), Kabupaten Cirebon (Setyawan et al., 2014), Kabupaten Brebes (Sinansari et al., 2016a), dan Kabupaten Gresik (Sinansari et al., 2016b). Robisalmi et al. (2016) melaporkan bahwa ikan nila srikandi dapat dijadikan sebagai komoditas alternatif untuk budidaya ikan di tambak bersalinitas tinggi dibandingkan dengan ikan nila nirwana dan nila merah.

Sejalan dengan semakin berkembangnya budidaya ikan nila maka kebutuhan pakannya juga semakin meningkat. Menurut Kontara et al. (2013), penggunaan pakan komersial cukup memberatkan bagi pembudidaya sehingga diperlukan alternatif pakan ikan menggunakan bahan baku lokal. Sekitar 70\% biaya produksi ikan nila digunakan untuk pembelian pakan, sementara suplai bahan baku pakan yang bervariasi lebih mengandalkan bahan baku impor sehingga harga pakan komersial semakin meningkat (Sunarno et al., 2017). Oleh karena itu, untuk memenuhi kebutuhkan pakan yang lebih ekonomis maka perlu pengembangan pakan berbasis bahan baku lokal dengan formulasi pakan yang tepat untuk ikan nila sehingga dapat menekan biaya produksi dan meningkatkan pendapatan pembudidaya.

Penyediaan pakan ekonomis melalui teknologi pakan mandiri berbasis bahan baku lokal merupakan alternatif untuk membantu pembudidaya ikan baik skala kecil maupun menengah. Pengembangan pakan berbasis bahan baku lokal dapat diartikan sebagai pakan mandiri karena kemandirian bahan baku untuk mengurangi impor bahan baku pakan. Selain itu, pakan mandiri juga diartikan sebagai pakan yang diproduksi denganpabrik pakan skala rumah tangga/kecil yang menggunakan peralatan sederhana dan bahan baku lokal (Rasidi \& Haryadi, 2016).

Beberapa lokasi juga telah mengembangkan pakan berbasis bahan baku lokal yang diaplikasikan untuk nila BEST (Bogor Enhanched Strain Tilapia) seperti di Kabupaten Pandeglang, Banten (Kontara et al., 2013; Insan et al., 2015) dan di Kabupaten Klungkung, Bali (Sunarno et al., 2017). Selain itu, beberapa daerah juga telah mengembangkan pakan mandiri seperti Kabupaten Sleman, Yogyakarta dan Sungai Gelam, Jambi (Rasidi \& Haryadi, 2016). Berdasarkan hal tersebut, perlu adanya penelitian pakan mandiri dan pengujiannya pada ikan nila srikandi yang dikembangkan di kawasan pesisir Kabupaten Brebes. Penelitian ini bertujuan menerapkan dan mengevaluasi penggunaan pakan mandiri pada budidaya ikan nila srikandi di Kabupaten Brebes, Jawa Tengah.

\section{BAHAN DAN METODE}

Penelitian dilakukan pada bulan Maret sampai November tahun 2016 di Kawasan Tambak Desa Randusanga Wetan Kecamatan Brebes Kabupaten Brebes, Jawa Tengah. Kegiatan penelitian dibagi menjadi dua, yaitu (a) survai pabrik mini pakan mandiri milik $\mathrm{H}$. Kasudi untuk mendapatkan pakan ikan nila hasil produksi pabrik tersebut yang pembuatan formulasi pakannya dibimbing oleh peneliti dari Balai Riset Perikanan Budidaya Air Tawar dan Penyuluhan Perikanan, Bogor (Kegiatan Model Penerapan IPTEK Tahun 2015); (b) pengujian pakan mandiri untuk pembesaran ikan nila srikandi yang dipelihara di tambak.

\section{Survei Pabrik Pakan Mandiri}

Data yang dikumpulkan meliputi harga pakan mandiri saat survei (tahun 2016), bahan baku pakan mandiri dan produksi pabrik pakan mandiri. Pada saat survei, $100 \mathrm{~g}$ sampel pakan mandiri dan pakan komersil ikan nila yang biasa digunakan oleh pembudidaya, diambil secara acak dan disimpan dalam kantong plastik berlabel untuk dianalisis. Analisis komposisi kimia pakan dilakukan di PT Saraswanti Indo Genetech, Bogor. Analisis proksimat pakan mandiri dan pakan komersil meliputi pengukuran kadar air merujuk pada SNI 01-2891-1992 butir 5.1; protein dengan 18-8-31/ MU/SM M-SIG, Kjeltec; lemak total merujuk pada SNI 01-2891-1992 butir 8.2; abu merujuk pada SNI 01-28911992 butir 6.1 ; karbohidrat total merujuk pada 18-89/MU/SMMG-SIG; energi total dan energi dari lemak dari pakan menggunakan metode perhitungan.

\section{Pakan Uji}

Pakan uji yang digunakan adalah pakan mandiri dari pabrik H. Kasudi dan sebagai pembanding digunakan 
pakan komersil yang biasa digunakan oleh pembudidaya setempat. Wadah pemeliharaan adalah tambak milik pembudidaya yang berukuran \pm 3.000 $\mathrm{m}^{2}$ sebanyak tiga petak. Waring hitam dipasang di bagian tengah sebagai pembatas membentang hingga masing-masing tambak dibagi menjadi dua bagian sehingga total menjadi enam unit percobaan. Setiap petak tambak yang terbagi dua, satu bagian untuk perlakukan pakan mandiri dan satu bagian untuk perlakuan pakan komersil.

\section{Pemeliharaan Ikan}

Ikan uji berupa ikan nila srikandi dengan ukuran rata-rata 2-3 cm/ekor, diperoleh dari Balai Riset Pemuliaan Ikan (BRPI), Sukamandi, Jawa Barat. Ikan tersebut terlebih dahulu diaklimatisasi di BRPI selama empat hari untuk adaptasi salinitas secara bertahap sampai mencapai salinitas 15 ppt agar benih tidak stres pada saat penebaran di tambak payau. Proses aklimatisasi menyesuaikan dengan standar operasional prosedur aklimatisasi pada BRPI (Balai Penelitian Pemuliaan Ikan, 2013).

Sebelum dilakukan penebaran ikan, tambak pemeliharaan diolah terlebih dahulu melalui beberapa tahap sesuai dengan standar operasional prosedur (SOP) dari BRPI. Tahapan tersebut yaitu pengeringan dasar tambak, perendaman dengan saponin, perbaikan saluran dan pintu air yang rusak, pengapuran, pengisian air, dan pemupukan tambak (Balai Penelitian Pemuliaan Ikan, 2013). Petak tambak kemudian diisi air dengan mengalirkan air dari sungai hingga mencapai kedalaman $80-100 \mathrm{~cm}$.

Ikan ditebar dengan kepadatan 10.000 ekor/petak tambak. Ikan dipelihara selama empat bulan dan diberi pakan sebanyak $1 \% 2 \%$ dari total biomassa ikan per hari pada pukul 07.00,12.00, dan 17.00. Pemeliharaan ikan pada bulan ke-1 dan ke-2 diberikan pakan harian sebanyak $1 \%$ dari biomassa, kemudian pemberian pakan ditingkatkan menjadi $2 \%$ pada pemeliharaan bulan ke-3 dan ke-4.

Sampling dilakukan setiap sebulan sekali dengan cara mengambil sampel secara acak dengan cara menjaring ikan pada tiga titik di setiap petakan tambak, kemudian diukur bobotnya. Pada akhir percobaan jumlah ikan ditimbang secara total (biomassa). Parameter yang diamati yaitu pertumbuhan, sintasan, dan laju pertumbuhan spesifik. Selama proses budidaya dilakukan pemantauan kualitas air (suhu, salinitas, pH, dan amoniak) dan performa pertumbuhan ikan, serta evaluasi terhadap pelaksanaan kegiatan budidaya ikan nila Srikandi secara keseluruhan.
Analisis usaha dilakukan untuk melihat apakah budidaya ikan nila Srikandi dengan menggunakan pakan mandiri tersebut layak atau tidak dengan melihat lima kriteria investasi yaitu net present value (NPV), net benefit cost ratio (Net $B / C$ ), internal rate of return (IRR), pay back period (PBP), dan break even point (BEP). Salah satu analisis usaha yang penting adalah dengan menghitung $\mathrm{R} / \mathrm{C}$ ratio yaitu kelayakan suatu usaha, yaitu apabila nilai R/C lebih besar dari satu maka usaha sudah layak dan sebaliknya. Pengaruh perlakuan terhadap parameter uji dianalisis secara statistik dengan uji-T pada tingkat kepercayaan $95 \%$

\section{HASIL DAN BAHASAN}

Hasil survei menunjukkan terdapat pabrik pakan mandiri di Kabupaten Brebes milik H. Kasudi. Pakan mandiri yang dibuat olah $\mathrm{H}$. Kasudi merupakan pakan berbasis bahan baku antara lain campuran dari tepung ikan, dedak, onggok (hasil samping pengolahan tapioka), tepung cangkang rajungan, tepung daging tulang, tepung kepala udang, bungkil kelapa, minyak ikan, dan beberapa vitamin, serta mineral. Pakan mandiri tersebut berhasil menarik minat pembudidaya untuk memanfaatkannya karena harganya yang relatif murah. Pakan mandiri produksi pabrik ini juga telah dimanfaatkandi daerah Cirebon. Selain mengelola pakan mandiri, H. Kasudi juga mengelola pabrik tepung ikan yang berada di Desa Losari Wetan Kecamatan Losari Kabupaten Brebes. Tepung ikan yang dihasilkan pabrik ini mempunyai kandungan protein mencapai $>50 \%$ dan telah dimanfaatkan oleh pabrik pakan ikan di daerah Lampung.

Pabrik pakan mandiri milik Bapak H. Kasudi telah mengaplikasikan pakan formula untuk ikan lele dan nila dengan bimbingan dari Balai Riset Perikanan Budidaya Air Tawar dan Penyuluhan Perikanan, Bogor dan mampu memproduksi pakan mandiri sebanyak 16 ton per hariyang telah didistribusikan di daerah Jawa Tengah, Jawa Barat, dan Jawa Timur. Pabrik pakan tersebut juga memproduksi dan menjual aneka pakan ikan seperti pakan ikan lele, bandeng dan nila.

\section{Performa Pertumbuhan Ikan Nila Srikandi di Tambak}

Hasil penelitian menunjukkan bahwa penggunaan pakan mandiri dan pakan komersil tidak memberikan pengaruh yang nyata pada performa pertumbuhan ikan nila srikandi $(P>0,05)$ (Gambar 1$)$.

Gambar 1 menunjukkan bahwa pada bulan pertama sejak benih ditebar (Juli s/d Agustus) pertumbuhan ikan masih sangat lambat, namun pada periode dua bulan terakhir pemeliharaan terlihat pertumbuhan ikan 


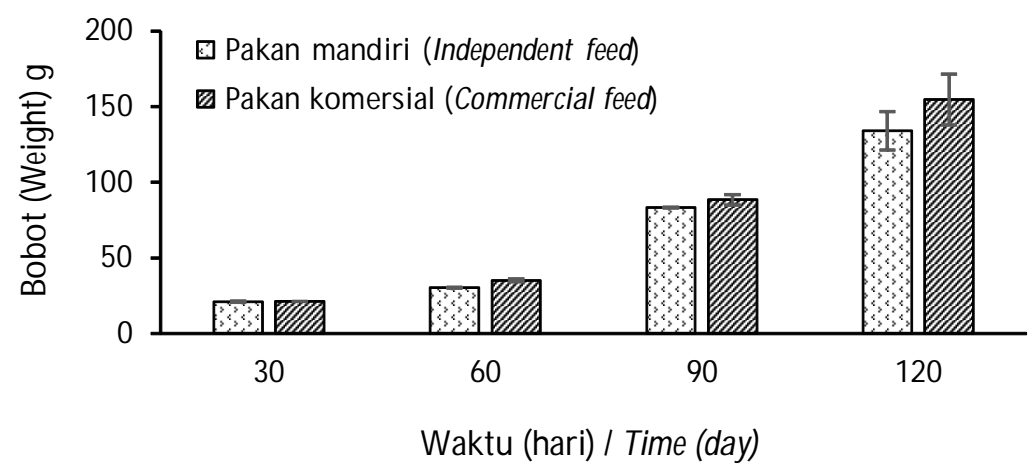

Gambar 1. Pola pertumbuhan ikan nila Srikandi selama 120 hari pemeliharaan.

Figure 1. The growth pattern of Srikandi tilapia during 120 days of feeding experiment.

meningkat dengan nyata pada kedua perlakuan. Namun berdasarkan uji statistik ternyata penggunaan pakan yang berbeda tidak memberikan pengaruh nyata terhadap laju pertumbuhan spesifik $(P>0,05)$. Hal ini diduga disebabkan karena ada perubahan dosis pakan selama pemeliharaan yaitu dari $1 \%$ menjadi $2 \%$ dari bobot tubuh, sehingga memengaruhi pertumbuhan ikan selama pemeliharaan dan total biomassa pada saat panen (Tabel 1). Pemberian pakan sebanyak $1 \%$ dari bobot biomassa sebenarnya belum memenuhi standar kebutuhan harian ikan (Setijaningsih et al., 2003; Alava, 2002; Rasidi \& Haryadi, 2016). Alasan pembudidaya hanya memberikan pakan sejumlah tersebut di atas karena sesuai dengan sifat ikan nila pada umumnya adalah omnivora sehingga diharapkan ikan nila dapat memanfaatkan pakan alami baik berupa hewan kecil dan berbagai jenis tanaman air yang tersedia di tambak (Widyanti, 2009).
Hasil percobaan menunjukkan bahwa penggunaan pakan mandiri memiliki nilai pertumbuhan yang tidak berbeda nyata dengan pakan komersil. Hal ini juga sesuai dengan hasil percobaan Sunarno et al. (2017) yang mendapatkan penggunaan pakan berbasis bahan baku lokal dengan pakan komersil memiliki pengaruh yang tidak berbeda terhadap pertumbuhan ikan nila BEST. Sama halnya dengan hasil penelitian Suhenda et al. (2011) yang menemukan bahwa aplikasi formula pakan dengan bahan baku lokal dan pakan komersil pada ikan lele juga memberikan hasil pertumbuhan yang tidak berbeda nyata. Hasil analisis proksimat terhadap dua jenis pakan uji menunjukkan bahwa komposisi proksimat kedua jenis pakan tersebut berbeda kandungan proteinnya, untuk pakan mandiri sebesar $23,40 \%$ dan pakan komersil sebesar $12,8 \%$ Namun, walaupun berbeda kadar protein tetapi memberikan hasil pertumbuhan yang tidak berbeda

Tabel 1. Pertumbuhan, sintasan, dan SGR ikan nila Srikandi selama 120 hari pemeliharaan

Table 1. Growth, survival, and SGR of Srikandi tilapia during 120 days of feeding experiment

\begin{tabular}{lcc}
\hline \multirow{2}{*}{ Parameter (Parameters) } & \multicolumn{2}{c}{ Jenis pakan (Type of diet) } \\
\cline { 2 - 3 } & Mandiri (Locally-produced) & Komersil (Commercial) \\
\hline Bobot awal (Initial weightl) (g) & $3.1 \pm 0.9$ & $3.1 \pm 0.9$ \\
Bobot akhir (Final weight) (g) & $133.92 \pm 52.37$ & $154 \pm 60.6$ \\
Biomassa awal (Initial biomass) (kg) & $28 \pm 0.42$ & $28 \pm 0.42$ \\
Biomassa akhir (Final biomass) (kg) & $2,214 \pm 172.69$ & $2,248.5 \pm 234.85$ \\
LPH (\%/hari) / SGR (\%day) & $2.83 \pm 0.01$ & $2.96 \pm 0.02$ \\
Sintasan (Survival rate) (\%) & $27.55 \pm 12.89$ & $24.22 \pm 15.18$ \\
\hline
\end{tabular}


nyata. Data pada Tabel 2 menunjukkan bahwa pakan mandiri dan pakan komersial mempunyai komposisi yang belum sesuai dengan SNI untuk pembesaran ikan nila, yaitu mengandung protein sekitar 29\%30\% Oleh karena itu, tidak memberikan pengaruh terhadap pertumbuhan maupun laju pertumbuhan spesifik pada ikan nila Srikandi. Hasil analisis proksimat pada kedua jenis pakan tersebut disajikan pada Tabel 2.

Hal ini menunjukkan bahwa pakan mandiri memiliki kualitas yang sedikit lebih baik daripada pakan komersil, sehingga dapat direkomendasikan kepada pembudidaya ikan. Menurut Suprayudi (2010), kualitas pakan ditentukan oleh kualitas bahan baku, formulasi, dan proses pembuatan pakan. Giri et al. (2009) juga mengemukakan bahwa formula pakan untuk ikan harus mengandung sumber energi dan asam amino esensial yang cukup, asam lemak esensial, spesifik vitamin, dan mineral untuk memacu pertumbuhannya. Menurut Rasidi \& Haryadi (2016), bahan baku pakan perlu diketahui komposisi nutrien yang terdiri atas protein dan asam amino, lipid dan asam lemak, karbohidrat, vitamin, dan mineral. Inilah sebabnya mengapa kualitas protein penting dalam nutrisi ikan.

Selama pemeliharaan, kualitas air juga diamati pada saat tebar karena sebelum penebaran benih ikan nila Srikandi diadaptasikan terlebih dahulu untuk menyesuaikan salinitas mendekati salinitas air tambak saat penebaran. Menurut Boyd (1990), kualitas air yang optimal untuk budidaya ikan yaitu pH kisaran 6,5-9,0; nitrit < 0,5 mg/L; dan amoniak < 1,0 mg/L. Hasil Kualitas air selama pemeliharaan disajikan pada Tabel 3.

\section{Analisis Usaha Pembudidaya}

Hasil perhitungan analisis usaha menunjukkan bahwa keuntungan dengan penggunaan pakan mandiri sedikit lebih tinggi jika dibandingkan dengan pakan komersil (Tabel 4). Total biaya produksi penggunakan pakan mandiri sebesar Rp18. 027.600,00 dan pakan komersil sebesar Rp22.194.500,00 yang dikeluarkan untuk usaha pembudidaya di Desa Randusanga Wetan Kecamatan Brebes Kabupaten Brebes dalam satu siklus pemeliharaan. Berbagai perhitungan dilakukan dalam analisis kegiatan ini seperti pendapatan kotor, keuntungan operasional, keuntungan bersih, rasio penerimaan dan biaya ( $\mathrm{R} / \mathrm{C}$ ratio), titik impas (BEP), dan masa pengembalian modal, pay back period (Gittinger, 2008).

Hasil penjualan ikan nila srikandi pada penggunaan pakan mandiri sebesar Rp26.568.000,00 dan pakan komersil sebesar Rp26.982.000,00 dengan harga jual ikan nila sebesar Rp12.000,00/kg. Tabel 5 menunjukkan bahwa titik balik/titik impas (break event poin/BEP) modal dapat tercapai apabila penjualan ikan nila Srikandi yang menggunakan pakan mandiri mencapai Rp3.357.900,00 dan pakan komersial mencapai Rp3.899.500,00. Selanjutnya nilai ROI sebesar 47,37\% pada aplikasi pakan mandiri menunjukan bahwajumlah investasi yang ditanamkan dapat menghasilkan keuntungan sebesar 47,37\% sedangkan pada aplikasi pakan komersil memberikan keuantungan sebesar $34,72 \%$

Nilai Revenue Cost Ratio (RC Rasio) R/C yang dimiliki pada usaha budidaya nila Srikandi di Brebes adalah 1,4 (pakan mandiri) dan 1,34 (pakan komersil). Dengan demikian, usaha tersebut layak untuk dilanjutkan karena nilai R/C lebih dari satu. Payback periode (PP), perhitungan ini mengukur seberapa cepat investasi usaha pembudidayaan nila Srikandi di Brebes dapat kembali. Hasil analisis ini menggambarkan bahwa seluruh modal investasi usaha budiaya ikan nila Srikandi di Brebes akan kembali dalam kurun waktu kurang dari satu tahun. Penentuan layak atau tidaknya suatu usaha adalah dengan cara membandingkan

Tabel 2. Komposisi proksimat pakan uji yang diberikan pada ikan nila Srikandi selama empat bulan pemeliharaan

Table 2. The proximate composition of the test feeds given to Srikandi tilapia

\begin{tabular}{lccc}
\hline \multicolumn{1}{c}{$\begin{array}{c}\text { Parameter } \\
\text { Parameters }\end{array}$} & $\begin{array}{c}\text { Pakan mandiri } \\
\text { Independently feed }\end{array}$ & $\begin{array}{c}\text { Pakan komersil } \\
\text { Commercial feed }\end{array}$ & $\begin{array}{c}\text { Satuan } \\
\text { Units }\end{array}$ \\
\hline Kadar air (M oisture) & 10.18 & 9.5 & $\%$ \\
Kadar abu (Ash) & 7.94 & 8.8 & $\%$ \\
Lemak total (Total lipid) & 7.70 & 6.2 & $\%$ \\
Protein (Crude protein) & 23.40 & 12.8 & $\%$ \\
Karbohidrat total (Total carbohydrate) & 50.78 & 62.6 & $\%$ \\
Energi total (Total energy) & 366.02 & 357.7 & kkal/100 g \\
Energi dari lemak (Energy from lipid) & 69.30 & 55.9 & kkal/100 g \\
\hline
\end{tabular}


Tabel 3. Kisaran parameter kualitas air tambak pemeliharaan ikan nila srikandi selama empat bulan pemeliharaan

Table 3. The range of water quality parameters in the pond during four months rearing period

\begin{tabular}{lcc}
\hline $\begin{array}{c}\text { Param eter } \\
\text { Parameters }\end{array}$ & $\begin{array}{c}\text { Awal pemeliharaan } \\
\text { Beginning of maintenance }\end{array}$ & $\begin{array}{c}\text { Sel ama pemeliharaan } \\
\text { During reared }\end{array}$ \\
\hline Suhu (Temperature) $\left({ }^{\circ} \mathrm{C}\right)$ & $29-32$ & $28-31$ \\
Salinitas (Salinity) $(\mathrm{ppt})$ & $20-25$ & $20-30$ \\
$\mathrm{pH}$ & $8.2-8.8$ & $6.5-8.5$ \\
Amoniak (Ammonia) $(\mathrm{g} / \mathrm{L})$ & 2.30 & $0.57-1.01$ \\
\hline
\end{tabular}

Tabel 4. Analisis usaha pembesaran ikan nila Srikandi yang diberi pakan komersil dan pakan mandiri selama empat bulan masa pemeliharaan di Kabupaten Brebes, Jawa Tengah

Table 4. Economic analysis of Srikandi tilapia fed with commercial diet and locally-produced feed and reared for four months in Brebes Regency of Central Java

\begin{tabular}{lcc}
\hline \multicolumn{1}{c}{ Uraian (Illustration) } & $\begin{array}{c}\text { Pakan mandiri } \\
\text { Independently feed }\end{array}$ & $\begin{array}{c}\text { Pakan komersil } \\
\text { Commercial feed }\end{array}$ \\
\hline Biaya investasi (Investment cost) (Rp) & $11,118,750$ & $11,118,750$ \\
Biaya operasional per siklus (Operating cost per cycle) (Rp) & & \\
a. Biaya tetap (Fixed cost) (Rp) & $1,208,850$ & $1,208,850$ \\
b. Biaya tidak tetap (Variable cost) (Rp) & $16,818,750$ & $20,985,750$ \\
Biaya total produksi (Total production cost) (Rp) & $18,027,600$ & $22,194,500$ \\
Pendapatan per siklus (Income per cycle) (Rp) & $26,568,600$ & $26,982,000$ \\
Keuntungan (Profits) (Rp) & $8,540,400$ & $6,954,400$ \\
Break event point (BEP) (Rp) & $3,357,900$ & $3,899,500$ \\
Break event point (BEP) (unit) & 0.12 & 0.15 \\
Return of invesment (ROI) (\%) & 47.37 & 34.72 \\
Revenue cost ratio (RC Rasio) & 1.4 & 1.34 \\
Pay back periode (PP) & 1.3 & 1.5 \\
\hline
\end{tabular}

masing-masing nilai kriteria kelayakan dengan batasbatas kelayakannya (Kadariah et al., 1999). Suatu teknologi dapat dikatakan berhasil apabila teknologi tersebut secara biologis dapat diatasi, secara teknis dapat memungkinkan untuk dilaksanakan, dan secara ekonomis dapat menguntungkan (Fatimah, 2010).

\section{KESIMPULAN}

Penggunaan pakan mandiri atau pakan komersil untuk pemeliharaan ikan Srikandi di tambak memberikan respons pertumbuhan ikan yang sama. Pakan mandiri dapat diterapkan untuk pemeliharaan ikan nila Srikandi di tambak.

\section{UCAPAN TERIMA KASIH}

Penelitian ini dibiayai oleh APBN Pusat Penelitian dan Pengembangan Perikanan TahunAnggaran 2016.
Ucapan terima kasih disampaikan kepada Dinas Kelautan dan Perikanan Kabupaten Brebes, para pembudidaya Desa Randusanga Wetan Kecamatan Brebes (Bapak Udin, Bapak Tarno, Bapak Jos Rosikin, Bapak Slamet, dan Bapak Zamroni) dan semua pihak yang telah membantu terlaksananya kegiatan penelitian ini.

\section{DAFTAR ACUAN}

Alava, V.R. (2002). Manajement of feeding aquaculture species. Nutrition in tropocal aquaculture essentials of fish nutrition, feed, and feeding of tropical aquatic species. Chapter 7. SEAFDEC. Iloil. Philippines, p. 169-205.

Balai Penelitian Pemuliaan Ikan. (2013). Petunjuk Teknis Budidaya Ikan Nila Srikandi. Pusat Penelitian dan Pengembangan Perikanan Budidaya. Badan 
Penelitian dan Pengembangan Kelautan dan Perikanan. Kementerian Kelautan dan Perikanan, $23 \mathrm{hlm}$.

Boyd, C.E. (1990) Water quality in ponds for aquaculture. Agriculture Experiment Station. Auburn University. Alabama, $482 \mathrm{pp}$.

Fatimah, D.E. (2010). Meraup untung besar dari budidaya nila. Yogyakarta: Lily Publisher, $74 \mathrm{hlm}$.

Giri, N.A., Sentika, A.S., Suwirya, K., \& Marzuqi, M. (2009). Kandungan asam amino lisin optimal dalam pakanuntuk pertumbuhan benih ikan kerapu sunu, Plectropomus leopardus. J. Ris. Akuakultur, 4(3), 357366.

Gittinger, J.P. (2008). Analisa ekonomi proyek-proyek pertanian. Jakarta: UI Press, $579 \mathrm{hlm}$.

Insan, I., Samsudin, R., Kontara, E.K., \& Savitri, E. (2015). Produktivitas budidaya ikan nila dengan pakan berbasis bahan baku lokal pada tipe kolam yang berbeda. Prosiding Forum Inovasi Teknologi Akuakultur, hlm. 385-389.

Kadariah, Karlina, L., \& Gray C. (1999). Pengantar evaluasi proyek. Fakultas Ekonomi Universitas Indonesia. Jakarta, $181 \mathrm{hlm}$.

Kontara, E.K., Samsudin, R., \& Sunarno, M.T. (2013). Pengembangan budidaya ikan nila (Oreochromis niloticus) di kolam tanah dengan aplikasi pakan berbasis bahan baku lokal. Prosiding Forum Inovasi Teknologi Akuakultur, hlm. 501-506.

Rasidi, \& Haryadi, J. (2016). Evaluasi kelayakan pakan mandiri. Prosiding Forum Inovasi Teknologi Akuakultur, hlm. 689-702.

Robisalmi, A., Setyawan, P., \& Gunadi, B. (2016). Performa pertumbuhan ikan nila nirwana (Oreochromis niloticus), ikan nila merah (0. niloticus $x 0$. mossambicus), ikan nila Srikandi (0. aureus $x 0$. niloticus), dan ikan nila biru (0. aureus) pada pemeliharaan di tambak. Prosiding Forum Inovasi Teknologi Akuakultur, hlm. 561-569.

Setijaningsih, L., Suhenda, N., Djajasewaka, H., \& Tahapari, E. (2003). Pengaruh perbedaan persentase protein terhadap retensi protein, energi, dan nilai kecernan pakan ikan nila (Oreochromis sp.). aplikasi teknologi pakan dan peranannya bagi perkembangan usaha perikanan budidaya. Prosiding Semi-Loka. Bogor, 9 September 2003, hlm. 155-158.
Setyawan, P. \& Dewi, R.R.S.P.S. (2013). Pemanfaatan ikan nila srikandi (Oreochromis aureus $x$ 0. niloticus) sebagai alternatif usaha potensial pada lahan sub optimal di Kecamatan Pekalongan Utara. Prosiding Forum Inovasi Teknologi Akuakultur, hlm. 67-71.

Setyawan, P., Robisalmi, A., \& Gunadi, B. (2013). Performa backcross antara ikan nila srikandi (Oreochromis aureus $x$ 0. niloticus) dan ikan nila biru (0. aureus) pada kolam pembesaran bersalinitas 25-30 ppt. Prosiding Forum Inovasi Teknologi Akuakultur, hlm. 601-607.

Setyawan, P., Dewi, R.R.S.P.S., Gunadi, B., \& Dwiyanti, D. (2014). Peningkatan produktivitas tambak melalui budidaya ikan nila Srikandi (Oreochromis aureus $x$ 0. niloticus). Prosiding Forum Inovasi Teknologi Akuakultur, hlm. 215-220.

Sinansari, S., Robisalmi, A., Priono, B., \& Kontara, E.K. (2016a). Studi evaluasi pertumbuhan ikan nila Srikandi pada tambak idle pondok Pesantren Imam Syafi'i Kabupaten Brebes, Jawa Tengah. Prosiding Forum Inovasi Teknologi Akuakultur, hlm. 345-350.

Sinansari, S., Setyawan, P., \& Fayumi, U. (2016b). Studi evaluasi pembesaran ikan nila Srikandi di Pondok Pesantren Roudlotul Yatim, Kabupaten Gresik, Jawa Timur. Prosiding Seminar Nasional Tahunan XIII Hasil Penelitian Perikanan dan Kelautan, Tahun 2016. Jilid I: Budidaya Perikanan. Departemen Perikanan Fakultas Pertanian Universitas Gadjah Mada. Yogyakarta, hlm. 317-323.

Suhenda, N., Samsudin, R., Teguh, \& Nugraha, A. (2011). Uji coba pakan berbasis bahan baku lokal untuk mendukung budidaya ikan lele di Kabupaten Banjarnegara. Laporan hasil riset BRPBAT, hlm. 3642.

Sunarno, M.T.D., Kusmini, I.I., \& Prakoso, V.A. (2017). Pemanfaatan bahan baku lokal di Klungkung, Bali untuk pakan ikan nila BEST (Oreochromis niloticus). Media Akuakultur, 12(2), 105-112.

Suprayudi. (2010). Bahan Baku Pakan Lokal. Tantangan dan Harapan Akuakultur Indonesia. Disampaikan dalam: Simposium Nasional Bioteknologi Akuakultur III. IPB International Convention Center. Bogor.

Widyanti, W. (2009). Kinerja pertumbuhan ikan nila (Oreochromis niloticus) yang diberi berbagai dosis enzim cairan rumen pada pakan berbasis daun lamtorogung, Leucaena leucocephala. Skripsi. Fakultas Perikanan dan IImu Kelautan. Institut Pertanian Bogor, $39 \mathrm{hlm}$. 